\title{
Association between Retinoic acid receptor- $\beta$ hypermethylation and NSCLC risk: a meta-analysis and literature review
}

\author{
Yan $\mathrm{Li}^{1}$, De-guo $\mathrm{Lu}^{2}$, Ying-mei $\mathrm{Ma}^{2}$ and Hongxiang $\mathrm{Liu}^{3}$ \\ ${ }^{1}$ Department of Respiratory, The Ninth People's Hospital of Chongqing, Chongqing, P. R. China \\ ${ }^{2}$ Clinical Laboratory, Linyi People's Hospital, Linyi, Shandong, P. R. China \\ ${ }^{3}$ Department of Cardiothoracic Surgery, Southwest Hospital, Third Military Medical University, Chongqing, P.R. China \\ Correspondence to: Hongxiang Liu, email: Hongxiangliva@yahoo.com \\ Keywords: RARß, methylation, lung cancer, meta-analysis, tumor suppressor gene \\ Received: September 06, 2016 Accepted: December 12, 2016 \\ Published: December 19, 2016
}

\section{ABSTRACT}

Emerging evidence indicates that Retinoic acid receptor- $\beta$ (RAR $\beta$ ) is a tumor suppressor in many types of tumor. However, whether or not RAR $\beta$ is a risk factor and is correlated to clinicopathological characteristics of non-small cell lung cancer (NSCLC) remains unclear. In this report, we performed a meta-analysis to determine the effects of RARB hypermethylation on the incidence of NSCLC and clinicopathological characteristics in human NSCLC patients. Final valuation and analysis of 1780 cancer patients from 16 eligible studies was performed. $R A R \beta$ hypermethylation was found to be significantly higher in NSCLC than in normal lung tissue, the pooled OR from 7 studies including 646 NSCLC and 580 normal lung tissues, OR $=6.05,95 \% \mathrm{CI}=3.56-$ $10.25, p<0.00001$. RARß hypermethylation was significantly higher in adenocarcinoma (AC) compared to squamous cell carcinoma (SCC), pooled OR is $0.68(95 \% \mathrm{CI}=$ $0.52-0.89, p=0.005)$. RAR $\beta$ hypermethylation was also found to occur significantly higher in smoker $(n=232)$ than non-smoker $(n=213)(O R=2.46,95 \%$ CI $=1.54-$ 3.93, $p=0.0002$ ). Our results indicate that $R A R \beta$ hypermethylation correlates well with an increased risk in NSCLC patients. RARB gene inactivation caused by RARB methylation contributes the NSCLC tumorigenesis and may serve as a potential risk factor, diagnostic marker and drug target of NSCLC.

\section{INTRODUCTION}

Non-small cell lung carcinoma (NSCLC) consists of squamous cell carcinoma (SCC), adenocarcinoma (AC), large cell carcinoma and others. There are approximately $80 \%$ of NSCLC cases in later stage where the treatment and prognosis is far from satisfactory [1]. Thus, identification of the risk factors and diagnostic markers is still needed for the prevention and the diagnosis of NSCLC patients. Epigenetic alterations, particularly aberrant DNA methylation, play a crucial role in cancer formation and progression [2-3]. Hypermethylation of $\mathrm{CpG}$ island in tumor suppressor gene promoter is a wellknown and typical epigenetic changes in cancer [2-4]. Nowadays the assay of gene promoter hypermethylation has not only been recognized as a remarkable tool for diagnosis of cancer, but also a prognosis factor to predict the cancer risk in a variety of cancers including NSCLC [5].
Retinoic acid (RA) and its derivative, retinoid can bind its three retinoic acid receptors (RAR), RAR $\alpha, \operatorname{RAR} \beta$ and RAR $\gamma$, are required for normal lung development [69]. Previous reports showed that $R A R \beta$ was frequently epigenetically silenced in tumor progression, which demonstrated that $R A R \beta$ belongs to a tumor suppressor protein [10-12]. $R A R \beta$ gene mutation was not reported in NSCLC. The loss of coactivators, such as AF2 coactivators of the RAR-Thyroid Hormone Receptor complex are often lost in human lung cancer and the loss of AF-2 cofactors results in low levels of transcribed RAR $\beta$ [13]. Silencing $R A R \beta$ by promoter hypermethylation has been found as one mechanism that regulates alveolar and epithelial differentiation and lung tumorigenesis [1415]. The hypermethylation of $R A R \beta$ in NSCLC has been reported inconsistently [16-17], although some groups indeed found that the inactivation of the $R A R \beta$ is caused by epigenetic progression, hypermethylation of $R A R \beta$ gene in NSCLC [16-17]. In addition, it is not clear whether $R A R \beta$ 
Table 1: Clinical features of selected studies

\begin{tabular}{|c|c|c|c|c|}
\hline Study & Country & Case No. & Methods & Goal \\
\hline $\begin{array}{l}\mathrm{Li}, \quad \text { et } \\
2014 \mathrm{a}[49]\end{array}$ & China & 167 & $\begin{array}{l}\text { Methylation } \\
\text { specific PCR (MSP) }\end{array}$ & $\begin{array}{l}\text { Determine whether tobacco exposure plays a role in gene } \\
\text { methylation }\end{array}$ \\
\hline $\begin{array}{l}\mathrm{Li}, \quad \text { et } \quad \text { al } \\
2014 \mathrm{~b}[37]\end{array}$ & China & 56 & MSP & $\begin{array}{l}\text { Determine the methylation status of three tumor suppressor } \\
\text { genes in NSCLC }\end{array}$ \\
\hline $\begin{array}{l}\text { Zhao, et al } \\
2012[50]\end{array}$ & China & 80 & MSP & $\begin{array}{l}\text { Detect methylation of the RAR } \beta \text { gene in tissues from NSCLC } \\
\text { patients }\end{array}$ \\
\hline $\begin{array}{l}\text { Scesnaite, et al } \\
2012[51]\end{array}$ & Finland & 212 & MSP & $\begin{array}{l}\text { Determine the methylation status of five tumor suppressor } \\
\text { genes in NSCLC }\end{array}$ \\
\hline $\begin{array}{l}\text { Yanagawa, et al } \\
2011[42]\end{array}$ & Japan & 62 & MSP & $\begin{array}{l}\text { Determine the methylation status of five tumor suppressor } \\
\text { genes in NSCLC }\end{array}$ \\
\hline $\begin{array}{l}\text { Zhang, et al } \\
2011[52]\end{array}$ & China & 200 & MSP & $\begin{array}{l}\text { Determine the methylation status of three tumor suppressor } \\
\text { genes in NSCLC }\end{array}$ \\
\hline $\begin{array}{l}\text { Liu, et al } 2010 \\
{[53]}\end{array}$ & China & 80 & MSP & $\begin{array}{l}\text { Access the methylation status of six tumor suppressor genes } \\
\text { in NSCLC }\end{array}$ \\
\hline $\begin{array}{l}\text { Hawes, et al } \\
2010[54]\end{array}$ & USA & 117 & $\begin{array}{l}\text { Methy } \\
\text { Light }\end{array}$ & Determine the DNA methylation status of 27 genes NSCLC \\
\hline $\begin{array}{l}\text { Kubo, et al } \\
2009[55]\end{array}$ & Japan & 100 & MSP & Examine the methylation status in five genes in NSCLC \\
\hline $\begin{array}{l}\text { Seng, et al } \\
2008[56]\end{array}$ & Australia & 239 & MSP & Investigate methylation status of three genes in NSCLC \\
\hline $\begin{array}{l}\text { Hsu, et al } \\
2007[57]\end{array}$ & China & 82 & MSP & Examine 19 genetic and epigenetic markers in NSCLC \\
\hline $\begin{array}{l}\text { Yanagawa, et al } \\
2007[17]\end{array}$ & Japan & 101 & MSP & Determine methylation in 10 genes in NSCLC \\
\hline $\begin{array}{l}\text { Kim, et al 2005a } \\
{[36]}\end{array}$ & Korea & 72 & MSP & Examine the DNA methylation status of five NSCLC \\
\hline $\begin{array}{l}\mathrm{Kim}, \text { et } \\
2005 \mathrm{~b}[58]\end{array}$ & Kerea & 61 & MSP & $\begin{array}{l}\text { Examine the methylation status of four tumor suppressor } \\
\text { genes in NSCLC }\end{array}$ \\
\hline $\begin{array}{l}\text { Tomizawa, et al } \\
2004[41]\end{array}$ & Japan & 120 & MSP & $\begin{array}{l}\text { Investigate aberrant methylation of } \\
\text { three genes in NSCLC }\end{array}$ \\
\hline $\begin{array}{l}\text { Topaloglu, et al } \\
2004[59]\end{array}$ & USA & 31 & MSP & $\begin{array}{l}\text { Examine the methylation status of eight tumor suppressor } \\
\text { genes in NSCLC }\end{array}$ \\
\hline
\end{tabular}

is associated with any clinical characteristics of NSCLC and predicts the risk of diseases. The discrepancy of the published data underpin the necessity to study the role of $R A R \beta$ inactivation by gene promoter hypermethylation in NSCLC. Therefore, we perform an evaluation on the role of $R A R \beta$ hypermethylation in lung tumorigenesis using a quantitative meta-analysis as well as a systematic review.

\section{RESULTS}

Sixteen publications which fitted into the inclusion criteria were collected into in this study. One hundred and ninety one publications were not included for the reasons such as in vivo animal work or in vitro cell culture model, non-original articles (review and editorial), or irrelevant publications. Figure 1 shows sixteen studies from 2004 to 2014 were included in the current meta-analysis. NSCLC patients from different countries such as China, South
Korea, Japan, Finland, Australia, and USA was included and counted 1780 cases. Their demographic information and clinical parameters are formatted into Table 1 .

By determine the $R A R \beta$ promoter hypermethylation using lung tissues, the NSCLC patients showed significantly higher $R A R \beta$ promter hypermethylation frequency than those of normal individuals. That is the $R A R \beta$ conveyed the positive association for promoter hypermethylation when comparing NSCLC tumors to normal controls, with the pooled OR of 6.05 (95\% CI $=3.56-10.25, p<0.00001)$ from 7 studies having both NSCLC tissues $(n=646)$ and normal lung tissues $(n=$ 580) (Figure 2). To further determine the association of $R A R \beta$ hypermethylation and two major pathological types, SCC and AC, total of 456 of SCC patients and 567 of AC patients in 8 studies were extracted. $R A R \beta$ hypermethylation was remarkably higher in AC patients in comparison to SCC patients with pooled OR of 0.68 


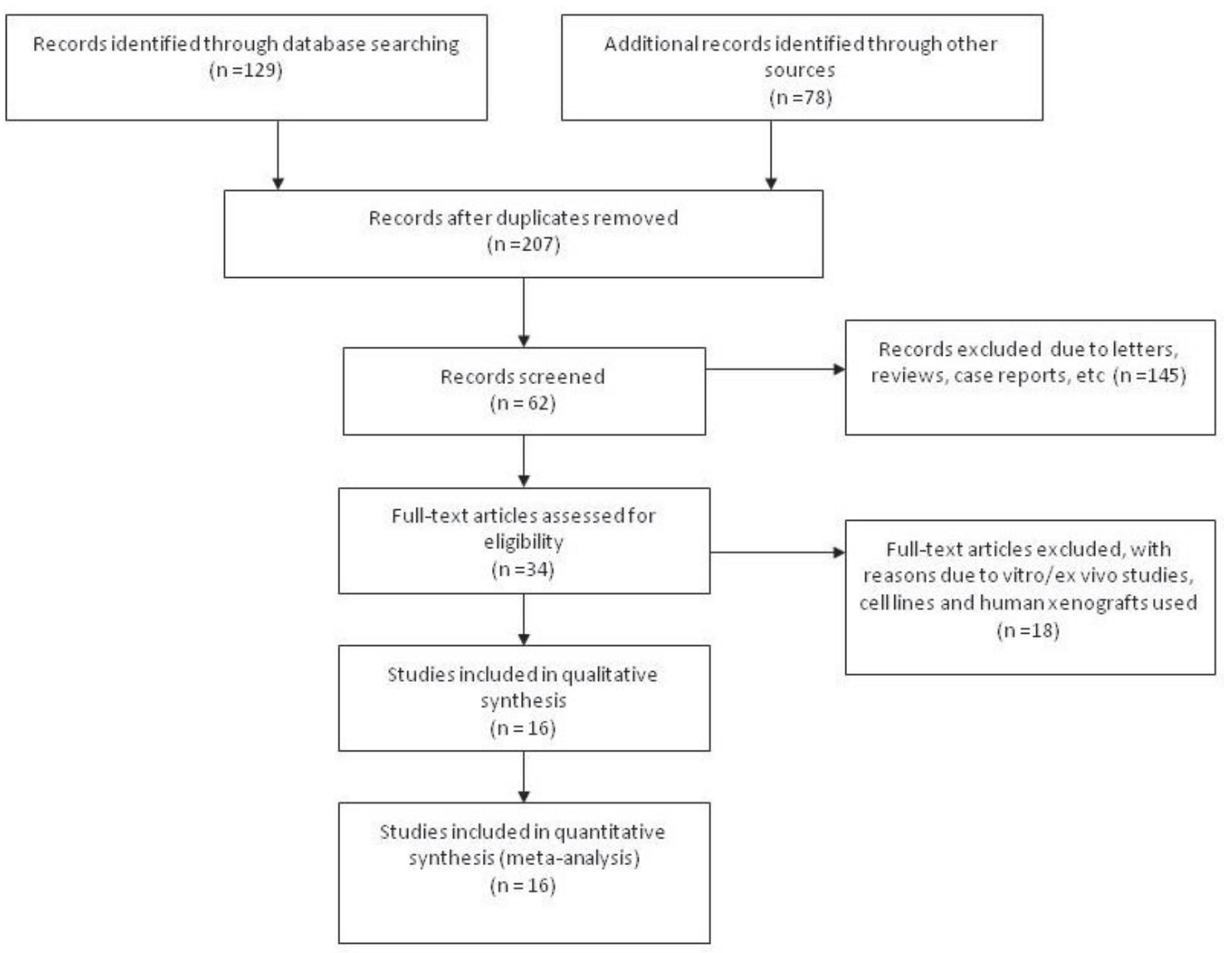

Figure 1: Flow chart of included study.

NSCLC Normal lung cancer Odds Ratio

Odds Ratio

Stuctyor Subgroulp Events Total Events Total Weight M.H,Random, $95 \% \mathrm{Cl} \quad$ M.H, Random, 95\% Cl

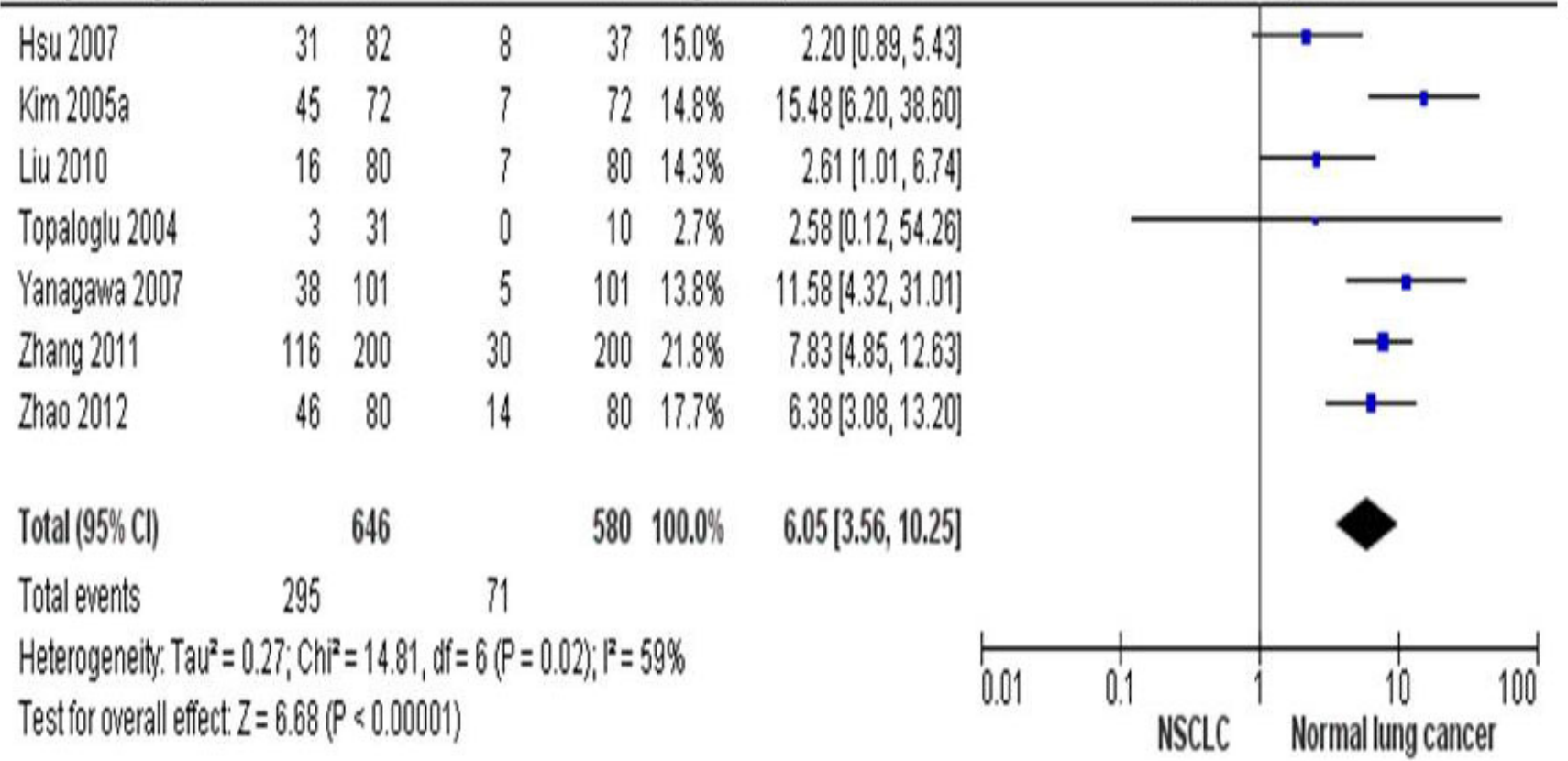

Figure 2: The combining estimates of the odds ratio from 7 selected studies containing lung tissues from 646 of NSCLC patients and 580 of normal individuals is $6.05(95 \% \mathrm{CI}, 3.56-10.25, p<0.00001)$. 
Syluamous cell carcinoma Adenocarcioma Odds Ratio Odds Ratio

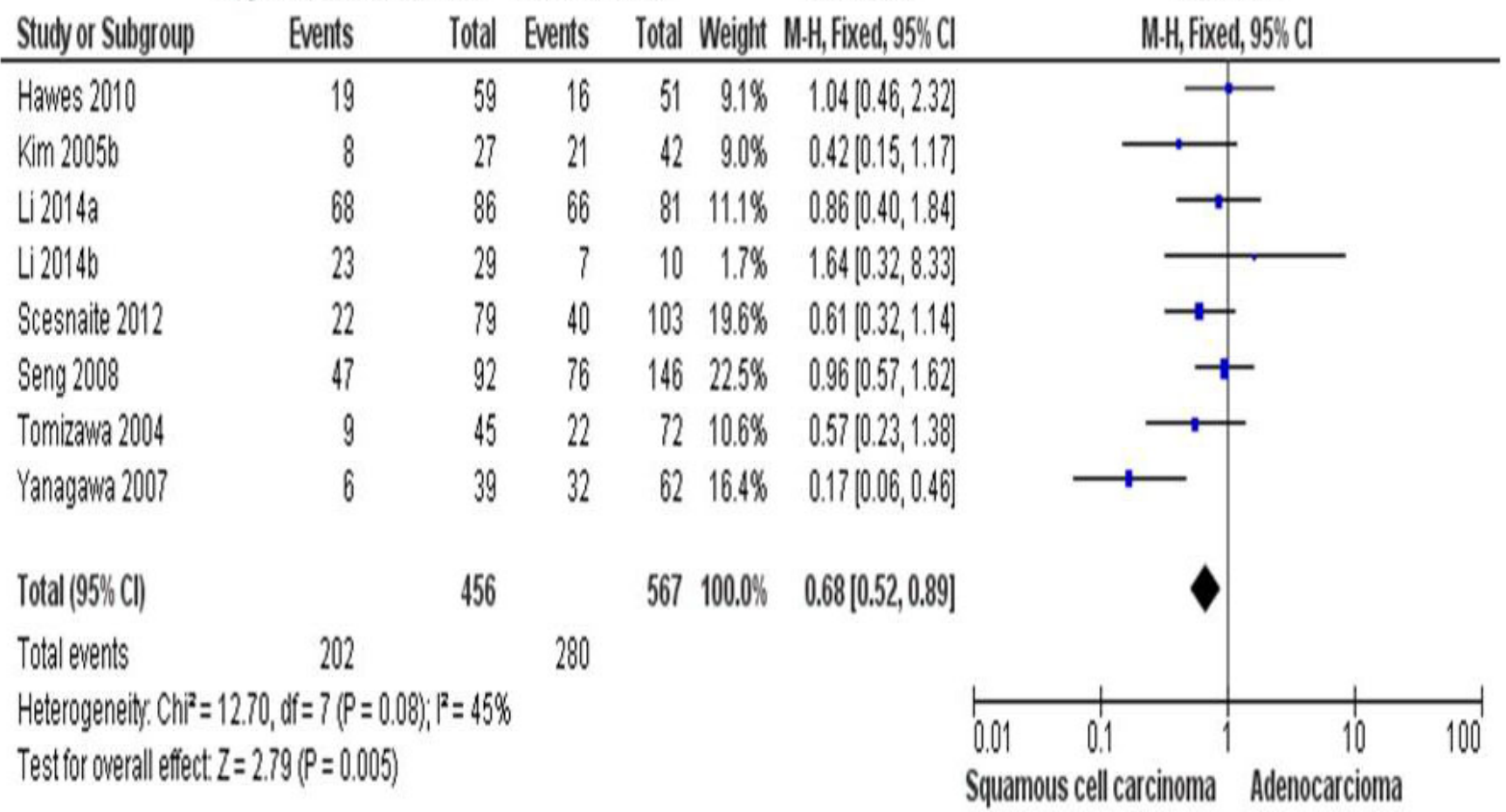

Figure 3: The combining estimates of the odds from 8 studies containing 456 of squamous cell carcinoma (SCC) and 567 of adenocarcinoma $(\mathrm{AC})$ is $0.68(95 \% \mathrm{C}, 0.52-0.89, p=0.005)$.

\section{Smoker Never Odds Ratio Odds Ratio}

Study or Subgroup Events Total Events Total Weight M.H, Fixed, $95 \% \mathrm{Cl} \quad \mathrm{M} \cdot \mathrm{H}, \mathrm{Fix}$.

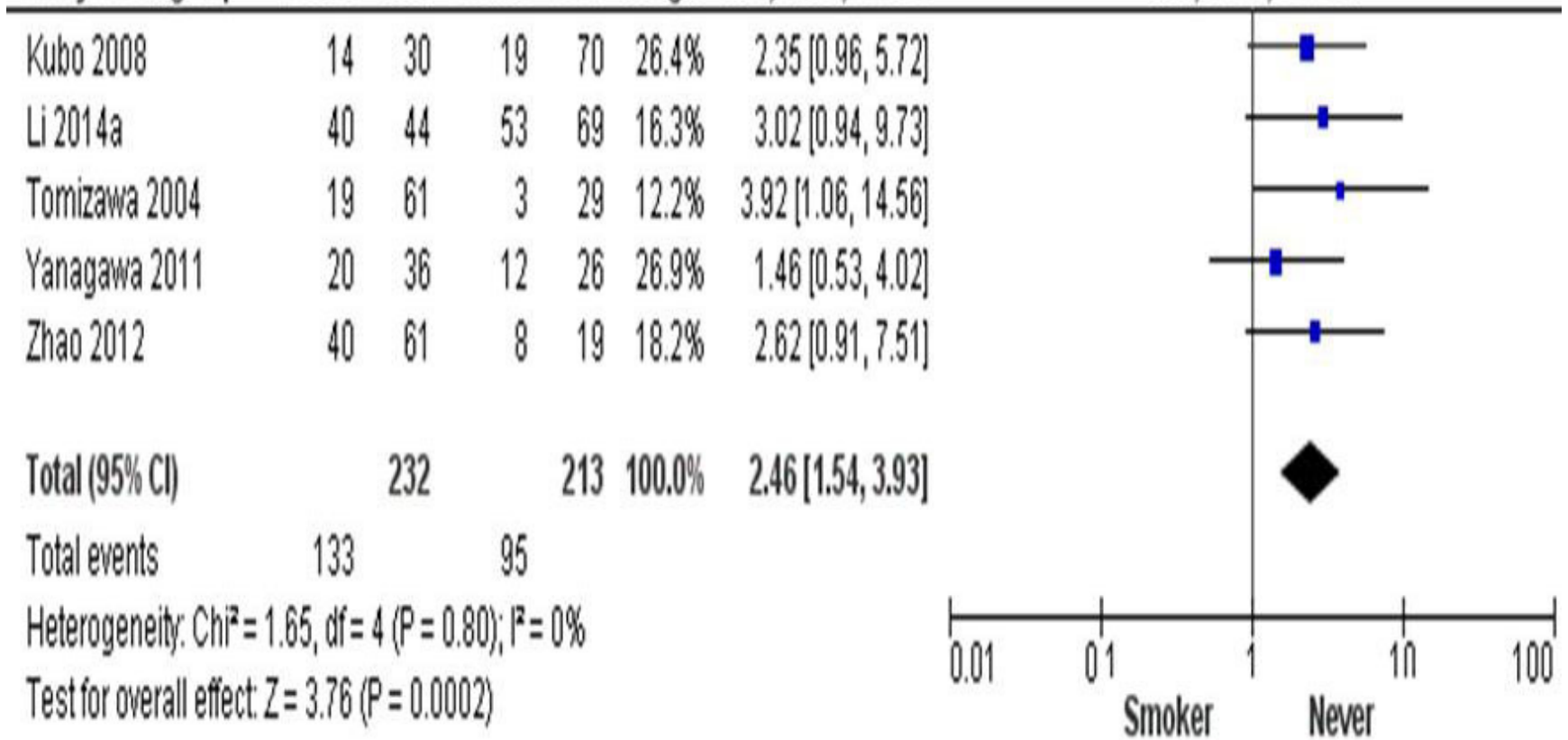

Figure 4: The combining estimates of the odds from 5 studies containing 232 and 213 NSCLC with and without smoking history is $2.46(95 \% \mathrm{CI}, .54-3.93, p=0.0002)$. 
(95\% CI $=0.52-0.89, p=0.005)$ (Figure 3). This result demonstrates that the hypermethylation $R A R \beta$ may have a crucial function in the lung tumorigenesis especially in AC formation.

After analysis of combining estimates of the OR from 5 studies of 445 of NSCLC (Figure 4), the rate of hypermethylation of $R A R \beta$ was detected significantly higher in smoker $(n=232)$ than non-smoker $(n=213)$ (OR $=2.46,95 \% \mathrm{CI}=1.54-3.93, p=0.0002)$. This indicates that $R A R \beta$ conveyed the positive association for promoter hypermethylation when comparing NSCLC smoker and NSCLC non-smoker.

Finally we removed one study at a time to calculate the sensitivity which is a sign of the analysis result stability. Neither the pooled ORs nor HRs were extremely altered, demonstrating the acceptable stability of the results. The symmetrical funnel plots as shown in Figure 5A-C imply no publication biases exist in the current study.

\section{DISCUSSION}

DNA methylation is an epigenetic mechanism that carried out by specific enzymes, the DNA methyltransferase enzymes [18-19]. In Eucaryotes, only cytosine belonging to $\mathrm{CG}$ dinucleotides, also named $\mathrm{CpG}$ in the $5^{\prime}$ position can be methylated, leading to the formation of 5-methylcytosine and are distributed in promoter regions of genes [20-21]. Just similar to other tumor suppressor genes, the $\mathrm{CpG}$ islands of $R A R \beta$ promoter are easily hypermethylated in malignant cells. Gene hypermethylation usually represses its transcription and plays an important role in the gene regulation. The $R A R \beta$ gene expression can cause RAdependent and RA-independent apoptosis and growth arrest, which is mediated through RAR $\alpha$ [22-23]. RAR $\beta$ protein results in the expression of a number of its target genes that mediate cell differentiation and death $[10,24-25] . R A R \beta$ is epigentically altered in many different kinds of human cancers. Inactivation of $R A R \beta$ by promoter hypermethylation contributes significantly to tumorigenesis of a variety of cancers including NSCLC [26-32]. Several groups have studied $R A R \beta$ methylation status in NSCLC; but the lack of systemic and quantitative analysis of methylation of $R A R \beta$ in NSCLC and its relationship with the clinical parameters really hampers the appreciation of mechanism of lung cancer as well as the development of novel tools for diagnosis and treatment of NSCLC patients. Analysis of the pooled data showed that there was a higher $R A R \beta$ hypermethylation in NSCLC patients when compared to normal lung tissue, indicating that $R A R \beta$ hypermethylation is risk factor in the carcinogenesis of NSCLC. $R A R \beta$ hypermethylation was also found to correlated with pathological types, as well as smoking status. Our findings that NSCLC patients have high frequencies
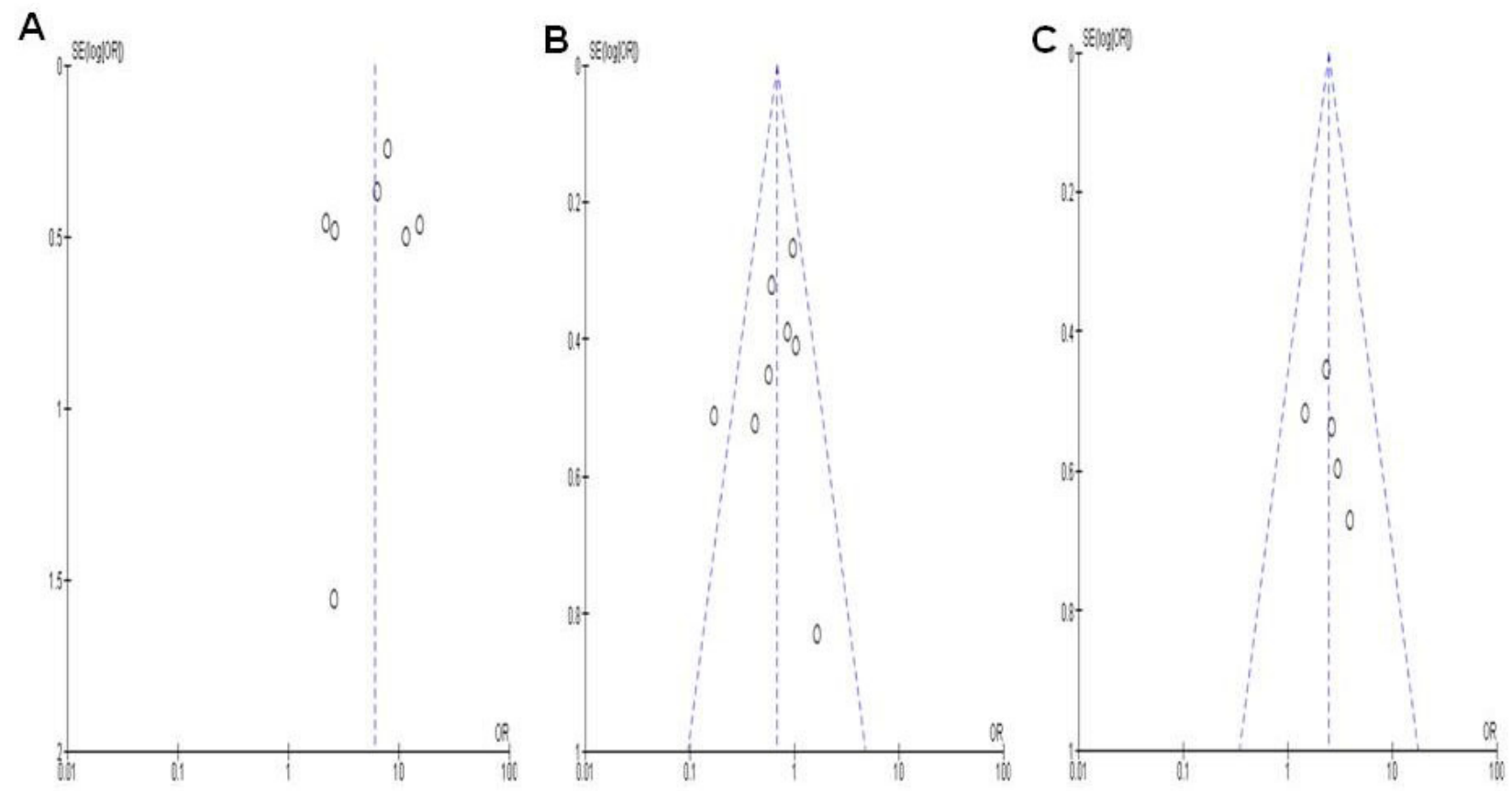

Figure 5: The symmetrical funnel plots demonstrates that no publication biases existed regarding $R A R \beta$ hypermethylation and clinicopathological features. Panel A. showed the funnel plot from 7 studies comparing NSCLC and normal lung tissue. Panel B. showed the funnel plot from 8 studies comparing RAR $\beta$ hypermethylation between squamous cell carcinoma (SCC) and adnocarcinoma (AC). Panel $\mathrm{C}$ showed the funnel plot from 5 studies examining the relationship between $R A R \beta$ hypermethylation and the smokers/ non-smokers in NSCLC patients C. X axis: value of Odds ratio (OR); Y axis: Standard errors (SE) multiply log scale of OR. 
of $R A R \beta$ gene promoter methylation compared to the normal lung tissues, indicating that the detection of $R A R \beta$ hypermethylation may provide a practical diagnostic marker for NSCLC patients. Unlike genetic changes, the reversible epigenetic modifications in $R A R \beta$ gene by methylation can be demethylated and therefore would be pratical to inhibit or delay carcinogenesis. Epigenetically silenced $R A R \beta$ has been shown to be re-expressed in the presence of histone deacetylase (HDAC) inhibitors and DNA methyltransferase inhibitors (DNMT) inhibitors in $R A R \beta 2$ silent cancer cells [33]. Treatment with 9-cis RA and an HDAC inhibitor showed effective in a cancer xenografts [34]. Four lung tumor lines treated with 5-aza2 '-deoxycytidine, restored RAR $\beta$ expression and resulted in decreased tumorigenicity [15]. In addition, curcumin can increase RAR $\beta$ expression at the mRNA and protein levels in lung cancer A549 and H460 cells, indicating that curcumin is able to inhibit $R A R \beta$ promoter methylation [35]. The clinical trials have shown the therapeutic potential by reactivation of tumor suppressor expression and may shed light on cancer treatment through genetargeted therapy.

A number of studies detected and compared the different rate of $R A R \beta$ hypermethylation; however, the results were contradictory due to limited number of patients from AC and SCC [36-37]. The combining estimates of the odds ratio from 8 publication having 456 $\mathrm{SCC}$ and $567 \mathrm{AC}$ is $\mathrm{OR}=0.68,95 \% \mathrm{CI}=0.52-0.89, p=$ 0.005 , which shows the rate of $R A R \beta$ hypermethylation was higher in AC than in SCC. In addition, studies have also reported a correlation between DNA methylation and tobacco carcinogens [38-42]. The combining estimates of the odds ratio from 5 studies having 232 and 213 NSCLC with and without smoking history is $\mathrm{OR}=2.46,95 \% \mathrm{CI}$ $=1.54-3.93, p=0.0002$, shows $R A R \beta$ hypermethylation significantly increased in smoking NSCLC patients compared to non-smoking NSCLC.

Publication bias did not exist after sensitivity analyses. However the study has several potential restrictions for some reasons. The language was limited to articles published in English. Publications in other languages were exluded due to unavailability of accurate medical translation. In addition, the selection biases could be possibly existed due to observational studies. Cancer cells may silence or repress RAR $\beta$ by mechanisms other than hypermethylation in NSCLC in order to initiate and promote their growth and resist treatment with RA. Therefore, cautions should be taken when our results are extrapolated to the general populations.

Taken together, our analysis showed a higher $R A R \beta$ hypermethylation in NSCLC than normal lung tissues, higher in $\mathrm{AC}$ than in $\mathrm{SCC}$, and higher in smokers than in non-smokers. $R A R \beta$ promoter hypermethylation, which inactivated $R A R \beta$ gene, may significantly contribute to the carcinogenesis and serve as a potential drug target and diagnostic marker for NSCLC patients.

\section{MATERIALS AND METHODS}

\section{Inclusion and exclusion criteria}

The database of Pubmed, Embase, and ISI web of knowledge were searched for publications from May 1, 1998 to December 2015 by the key words: "lung" and "cancer or tumor or neoplasm or carcinoma", "methylation", and "RAR $\beta$ or retinoic acid receptor- $\beta$ or NR1B2". In addition, the author bibliographies were also searched manually from the retrieved publications for additional papers.

After withdraw of irrelevant and/or repeated publications from various resources, the remaining papers in the full text were evaluated for selection according to inclusion and exclusion criteria. All searched papers were retrieved. The cited references of selected studies were also determined for other relevant studies. Only one complete study was selected if same patient populations were repeatedly reported.

The inclusion criteria for eligibility include: (1) $R A R \beta$ hypermethylation was determined in the lung tissues of primary NSCLC patients, (2) $R A R \beta$ promoter hypermethylation was detected by polymerase chain reaction (PCR), (3) the data provided the information on both status of $R A R \beta$ hypermethylation as well as clinicopathological indexes of the NSCLC patients (4) the statistic information was given such as individual hazard ratio (HR) of overall survival (OS) and $95 \%$ confidence interval (CI). However, the Letters, reviews, case reports, conference abstracts, editorials, expert opinion, and all research which are involved in vitro/ex vivo studies were not included.

\section{Extraction methods}

We reviewed the following information in each eligible study, authorship, time of publication, sample collection, case numbers, clinicopathological information, the techniques used to calculate gene promoter methylation, methylation frequences and/or gene product expression, and the process of follow-up. Disagreements between the analyzers were fully discussed until come to an agreement. Demographic data and clinical responses were formatted into a table. Heterogeneity of study was calculated to determine if the dataset were suitable for a meta-analysis.

The methodology of each study was evaluated and scored based on the REMARK and ELCWP guidelines [43-44]. 


\section{Statistical analysis}

Analysis was performed by the softwares of STATA 12.0 (Stata Corporation, TX, USA) and Review Manager 5.2 (Cochrane Collaboration, Oxford, UK). The pooled ratios of $R A R \beta$ promoter hypermethylation and $95 \%$ confidence intervals $(95 \% \mathrm{CI})$ were calculated. The frequency of $R A R \beta$ hypermethylation was analyzed and correlated to various tumor phenotypes. Heterogeneity among studies was calculated by Cochran's Q test [45] which showed by the $I^{2}$ [46-47]. When heterogeneity did not exist $\left(I^{2}\right.$ values $\left.<50 \%\right)$, a fixed effect model was utilized. On the contrary, a random-effects model was utilized to pool individual data together. In addition, potential sources of heterogeneity were identified by further subgroup analyses. The existence of an association between $R A R \beta$ promoter hypermethylation and clinicopathological indexes were determined by a pooled OR. $P$ values less than 0.05 was considered significant level.

Publication bias was assessed by using a method reported by Egger et al [48]. We also explored reasons for statistical heterogeneity using meta-regression, subgroup analysis, and sensitivity analysis. The analysis of metaregression and publication bias were performed by using STATA version 10.0.

\section{CONFLICTS OF INTEREST}

The authors declare that they have no conflict of interest.

\section{Authors' contribution}

YL, DL, HL participated in the design of the study; YL, DL performed experiments; YL, YM, and HL analyzed data; YL, HL wrote the manuscript; All authors reviewed the manuscript.

\section{REFERENCES}

1. Ramalingam S and Belani C. Systemic chemotherapy for advanced non-small cell lung cancer: recent advances and future directions. Oncologist. 2008; 13 Suppl 1:5-13.

2. Delpu Y, Cordelier P, Cho WC and Torrisani J. DNA methylation and cancer diagnosis. Int J Mol Sci. 2013; 14(7):15029-15058.

3. Ma X, Wang YW, Zhang MQ and Gazdar AF. DNA methylation data analysis and its application to cancer research. Epigenomics. 2013; 5(3):301-316.

4. Ghavifekr Fakhr M, Farshdousti Hagh M, Shanehbandi D and Baradaran B. DNA Methylation Pattern as Important Epigenetic Criterion in Cancer. Genet Res Int. 2013; 2013(23):317569.
5. Fleischhacker M, Dietrich D, Liebenberg V, Field JK and Schmidt B. The role of DNA methylation as biomarkers in the clinical management of lung cancer. Expert Rev Respir Med. 2013; 7(4):363-383.

6. Grummer MA, Thet LA and Zachman RD. Expression of retinoic acid receptor genes in fetal and newborn rat lung. Pediatr Pulmonol. 1994; 17(4):234-238.

7. Mendelsohn C, Lohnes D, Decimo D, Lufkin T, LeMeur $\mathrm{M}$, Chambon $\mathrm{P}$ and Mark M. Function of the retinoic acid receptors (RARs) during development (II). Multiple abnormalities at various stages of organogenesis in RAR double mutants. Development. 1994; 120(10):2749-2771.

8. Chytil F. Retinoids in lung development. FASEB J. 1996; 10(9):986-992.

9. Minna JD and Mangelsdorf DJ. Retinoic acid receptor expression abnormalities in lung cancer: important clues or major obstacles? J Natl Cancer Inst. 1997; 89(9):602-604.

10. Alvarez S, Germain P, Alvarez R, Rodriguez-Barrios $\mathrm{F}$, Gronemeyer $\mathrm{H}$ and de LAR. Structure, function and modulation of retinoic acid receptor beta, a tumor suppressor. Int J Biochem Cell Biol. 2007; 39(7-8):14061415.

11. Mongan NP and Gudas LJ. Diverse actions of retinoid receptors in cancer prevention and treatment. Differentiation. 2007; 75(9):853-870.

12. Swift CB, Hays JL and Petty WJ. Distinct functions of retinoic acid receptor beta isoforms: implications for targeted therapy. Endocr Metab Immune Disord Drug Targets. 2008; 8(1):47-50.

13. Moghal N and Neel BG. Evidence for impaired retinoic acid receptor-thyroid hormone receptor AF-2 cofactor activity in human lung cancer. Mol Cell Biol. 1995; 15(7):3945-3959.

14. Licchesi JD, Westra WH, Hooker CM and Herman JG. Promoter hypermethylation of hallmark cancer genes in atypical adenomatous hyperplasia of the lung. Clin Cancer Res. 2008; 14(9):2570-2578.

15. Virmani AK, Rathi A, Zochbauer-Muller S, Sacchi N, Fukuyama Y, Bryant D, Maitra A, Heda S, Fong KM, Thunnissen F, Minna JD and Gazdar AF. Promoter methylation and silencing of the retinoic acid receptorbeta gene in lung carcinomas. J Natl Cancer Inst. 2000; 92(16):1303-1307.

16. Umemura S, Fujimoto N, Hiraki A, Gemba K, Takigawa N, Fujiwara K, Fujii M, Umemura H, Satoh M, Tabata M, Ueoka H, Kiura K, Kishimoto T and Tanimoto M. Aberrant promoter hypermethylation in serum DNA from patients with silicosis. Carcinogenesis. 2008; 29(9):1845-1849.

17. Yanagawa N, Tamura G, Oizumi H, Kanauchi N, Endoh M, Sadahiro M and Motoyama T. Promoter hypermethylation of RASSF1A and RUNX3 genes as an independent prognostic prediction marker in surgically resected nonsmall cell lung cancers. Lung Cancer. 2007; 58(1):131-138.

18. Bestor TH. Gene silencing as a threat to the success of gene therapy. J Clin Invest. 2000; 105(4):409-411. 
19. Hamidi T, Singh AK and Chen T. Genetic alterations of DNA methylation machinery in human diseases. Epigenomics. 2015; 7(2):247-265.

20. Kulis M, Queiros AC, Beekman R and Martin-Subero JI. Intragenic DNA methylation in transcriptional regulation, normal differentiation and cancer. Biochim Biophys Acta. 2013; 1829(11):1161-1174.

21. Klutstein M, Nejman D, Greenfield R and Cedar H. DNA Methylation in Cancer and Aging. Cancer Res. 2016; 76(12):3446-3450.

22. Liu Y, Lee MO, Wang HG, Li Y, Hashimoto Y, Klaus M, Reed JC and Zhang X. Retinoic acid receptor beta mediates the growth-inhibitory effect of retinoic acid by promoting apoptosis in human breast cancer cells. Mol Cell Biol. 1996; 16(3):1138-1149.

23. Chambon P. A decade of molecular biology of retinoic acid receptors. FASEB J. 1996; 10(9):940-954.

24. Bushue $\mathrm{N}$ and Wan YJ. Retinoid pathway and cancer therapeutics. Adv Drug Deliv Rev. 2010; 62(13):12851298.

25. Tang XH and Gudas LJ. Retinoids, retinoic acid receptors, and cancer. Annu Rev Pathol. 2011; 6:345-364.

26. Hua F, Fang N, Li X, Zhu S, Zhang W and Gu J. A meta-analysis of the relationship between RARbeta gene promoter methylation and non-small cell lung cancer. Plos one. 2014; 9(5):e96163.

27. Chen R, Ren S, Meng T, Aguilar J and Sun Y. Impact of glutathione-S-transferases (GST) polymorphisms and hypermethylation of relevant genes on risk of prostate cancer biochemical recurrence: a meta-analysis. Plos one. 2013; 8(9):e74775.

28. Moison C, Assemat F, Daunay A, Tost J, Guieysse-Peugeot AL and Arimondo PB. Synergistic chromatin repression of the tumor suppressor gene RARB in human prostate cancers. Epigenetics. 2014; 9(4):477-482.

29. Li W, Deng J, Jiang P, Zeng X, Hu S and Tang J. Methylation of the RASSF1A and RARbeta genes as a candidate biomarker for lung cancer. Exp Ther Med. 2012; 3(6):1067-1071.

30. Piperi C, Themistocleous MS, Papavassiliou GA, Farmaki E, Levidou G, Korkolopoulou P, Adamopoulos C and Papavassiliou AG. High incidence of MGMT and RARbeta promoter methylation in primary glioblastomas: association with histopathological characteristics, inflammatory mediators and clinical outcome. Mol Med. 2010; 16(1-2):19.

31. Shukla S, Mirza S, Sharma G, Parshad R, Gupta SD and Ralhan R. Detection of RASSF1A and RARbeta hypermethylation in serum DNA from breast cancer patients. Epigenetics. 2006; 1(2):88-93.

32. Fischer JR, Ohnmacht U, Rieger N, Zemaitis M, Stoffregen C, Kostrzewa M, Buchholz E, Manegold C and Lahm H. Promoter methylation of RASSF1A, RARbeta and DAPK predict poor prognosis of patients with malignant mesothelioma. Lung Cancer. 2006; 54(1):109-116.

33. Sirchia SM, Ren M, Pili R, Sironi E, Somenzi G, Ghidoni R, Toma S, Nicolo G and Sacchi N. Endogenous reactivation of the RARbeta2 tumor suppressor gene epigenetically silenced in breast cancer. Cancer Res. 2002; 62(9):24552461.

34. Qian DZ, Ren M, Wei Y, Wang X, van dGF, Rasmussen C, Nakanishi O, Sacchi $\mathrm{N}$ and Pili R. In vivo imaging of retinoic acid receptor beta2 transcriptional activation by the histone deacetylase inhibitor MS-275 in retinoid-resistant prostate cancer cells. Prostate. 2005; 64(1):20-28.

35. Jiang A, Wang X, Shan X, Li Y, Wang P, Jiang P and Feng Q. Curcumin Reactivates Silenced Tumor Suppressor Gene RARbeta by Reducing DNA Methylation. Phytother Res. 2015; 29(8):1237-1245.

36. Kim YT, Park SJ, Lee SH, Kang HJ, Hahn S, Kang $\mathrm{CH}$, Sung SW and Kim JH. Prognostic implication of aberrant promoter hypermethylation of $\mathrm{CpG}$ islands in adenocarcinoma of the lung. J Thorac Cardiovasc Surg. 2005; 130(5):1378.

37. Li W, Deng J and Tang JX. Combined effects methylation of FHIT, RASSF1A and RARbeta genes on non-small cell lung cancer in the Chinese population. Asian Pac J Cancer Prev. 2014; 15(13):5233-5237.

38. Lee YW, Klein CB, Kargacin B, Salnikow K, Kitahara J, Dowjat K, Zhitkovich A, Christie NT and Costa M. Carcinogenic nickel silences gene expression by chromatin condensation and DNA methylation: a new model for epigenetic carcinogens. Mol Cell Biol. 1995; 15(5):25472557.

39. Swafford DS, Middleton SK, Palmisano WA, Nikula KJ, Tesfaigzi J, Baylin SB, Herman JG and Belinsky SA. Frequent aberrant methylation of p16INK4a in primary rat lung tumors. Mol Cell Biol. 1997; 17(3):1366-1374.

40. Rom WN, Hay JG, Lee TC, Jiang Y and Tchou-Wong KM. Molecular and genetic aspects of lung cancer. Am J Respir Crit Care Med. 2000; 161(4 Pt 1):1355-1367.

41. Tomizawa Y, Iijima H, Nomoto T, Iwasaki Y, Otani Y, Tsuchiya S, Saito R, Dobashi K, Nakajima T and Mori M. Clinicopathological significance of aberrant methylation of RARbeta2 at 3p24, RASSF1A at 3p21.3, and FHIT at 3 p14.2 in patients with non-small cell lung cancer. Lung Cancer. 2004; 46(3):305-312.

42. Yanagawa N, Tamura G, Oizumi H, Endoh M, Sadahiro $\mathrm{M}$ and Motoyama T. Inverse correlation between EGFR mutation and FHIT, RASSF1A and RUNX3 methylation in lung adenocarcinoma: relation with smoking status. Anticancer Res. 2011; 31(4):1211-1214.

43. McShane LM, Altman DG, Sauerbrei W, Taube SE, Gion $\mathrm{M}$ and Clark GM. Reporting recommendations for tumor marker prognostic studies (REMARK). J Natl Cancer Inst. 2005; 97(16):1180-1184.

44. Steels E, Paesmans M, Berghmans T, Branle F, Lemaitre F, Mascaux C, Meert AP, Vallot F, Lafitte JJ and Sculier 
JP. Role of p53 as a prognostic factor for survival in lung cancer: a systematic review of the literature with a metaanalysis. Eur Respir J. 2001; 18(4):705-719.

45. DerSimonian R and Laird N. Meta-analysis in clinical trials. Control Clin Trials. 1986; 7(3):177-188.

46. Higgins JP, Thompson SG, Deeks JJ and Altman DG. Measuring inconsistency in meta-analyses. BMJ. 2003; 327(7414):557-560.

47. DerSimonian R. Meta-analysis in the design and monitoring of clinical trials. Stat Med. 1996; 15(12):1237-1248; discussion 1249-1252.

48. Egger M, Davey Smith G, Schneider M and Minder C. Bias in meta-analysis detected by a simple, graphical test. BMJ. 1997; 315(7109):629-634.

49. Li W, Deng J, Wang SS, Ma L, Pei J, Zeng XX and Tang JX. Association of methylation of the RAR-beta gene with cigarette smoking in non-small cell lung cancer with Southern-Central Chinese population. Asian Pac J Cancer Prev. 2014; 15(24):10937-10941.

50. Zhao X, Wang N, Zhang M, Xue S, Shi K and Chen Z. Detection of methylation of the RAR-beta gene in patients with non-small cell lung cancer. Oncol Lett. 2012; 3(3):654658.

51. Scesnaite A, Jarmalaite S, Mutanen P, Anttila S, Nyberg F, Benhamou S, Boffetta P and Husgafvel-Pursiainen K. Similar DNA methylation pattern in lung tumours from smokers and never-smokers with second-hand tobacco smoke exposure. Mutagenesis. 2012; 27(4):423-429.

52. Zhang CY, Jin YT, Xu HY, Zhang H, Zhang WM, Sun $\mathrm{XY}$, Tan $\mathrm{C}$ and Chen CM. [Relationship between promoter methylation of p16, DAPK and RAR beta genes and the clinical data of non-small cell lung cancer]. Zhonghua Yi Xue Yi Chuan Xue Za Zhi. 2011; 28(1):23-28.

53. Liu Z, Li W, Lei Z, Zhao J, Chen XF, Liu R, Peng X, Wu ZH, Chen J, Liu H, Zhou QH and Zhang HT. CpG island methylator phenotype involving chromosome $3 p$ confers an increased risk of non-small cell lung cancer. J Thorac Oncol. 2010; 5(6):790-797.

54. Hawes SE, Stern JE, Feng Q, Wiens LW, Rasey JS, Lu $\mathrm{H}$, Kiviat NB and Vesselle H. DNA hypermethylation of tumors from non-small cell lung cancer (NSCLC) patients is associated with gender and histologic type. Lung Cancer. 2010; 69(2):172-179.

55. Kubo T, Yamamoto H, Ichimura K, Jida M, Hayashi T, Otani H, Tsukuda K, Sano Y, Kiura K and Toyooka S. DNA methylation in small lung adenocarcinoma with bronchioloalveolar carcinoma components. Lung Cancer. 2009; 65(3):328-332.

56. Seng TJ, Currey N, Cooper WA, Lee CS, Chan C, Horvath L, Sutherland RL, Kennedy C, McCaughan B and KohonenCorish MR. DLEC1 and MLH1 promoter methylation are associated with poor prognosis in non-small cell lung carcinoma. Br J Cancer. 2008; 99(2):375-382.

57. Hsu HS, Chen TP, Wen CK, Hung CH, Chen CY, Chen JT and Wang YC. Multiple genetic and epigenetic biomarkers for lung cancer detection in cytologically negative sputum and a nested case-control study for risk assessment. J Pathol. 2007; 213(4):412-419.

58. Kim YT, Lee SH, Sung SW and Kim JH. Can aberrant promoter hypermethylation of $\mathrm{CpG}$ islands predict the clinical outcome of non-small cell lung cancer after curative resection? Ann Thorac Surg. 2005; 79(4):1180-1188; discussion 1180-1188.

59. Topaloglu O, Hoque MO, Tokumaru Y, Lee J, Ratovitski E, Sidransky D and Moon CS. Detection of promoter hypermethylation of multiple genes in the tumor and bronchoalveolar lavage of patients with lung cancer. Clin Cancer Res. 2004; 10(7):2284-2288. 